\title{
At-Taqaddum
}

Vol. 10 No. 2 (2018) pp 143-168

DOI: http://dx.doi.org/10.21580/at.v10i2.2986

\section{KEMAMPUAN MEMAHAMI PERCAKAPAN MENGGUNAKAN BAHASA INDONESIA BAGI MAHASISWA ASING DI UIN WALISONGO SEMARANG}

Maya Rini Handayani

Universitas Islam Negeri Walisongo Semarang

Email: mayarinihandayani@walisongo.ac.id

\begin{abstract}
This article discusses the understanding of conversation skills using Bahasa. Respondents of this article were foreign students from South Thailand. They registered in UIN Walisongo Semarang in various departments and academic years. The ability to listen Bahasa was an indicator in this research. The 37 respondents were students from 2012 till 2016, who aged between 20 to 28 years old. The 25 students were female while the 12 others were male students. Data were collected by using questionnaires. The article result shows that the average of students' ability to listen Bahasa are in score 20. This score is 19 to 20, it occupied in medium category. The category used five standard intervals, namely very high, high, medium, low, and very low. The summary of this research is the understanding skill of conversation of foreign students using Bahasa is in a medium category.
\end{abstract}

Keywords : Bahasa, understanding skill, students of South Thailand

\begin{abstract}
Abstrak
Artikel ini membahas mengenai kemampuan responden dalam memahami sebuah percakapan menggunakan bahasa Indonesia. Responden merupakan mahasiswa asing yang berasal dari kelompok propinsi Thailand Selatan. Responden menempuh pendidikan di UIN Walisongo Semarang dengan jurusan dan angkatan yang berbeda. Indikator yang digunakan dalam penelitian ini adalah kemampuan mendengar percakapan menggunakan bahasa Indonesia. Responden berjumlah 37 orang dengan rentang usia berkisar antara 20 hingga 28
\end{abstract}


tahunan berasal dari angkatan 2012 hingga 2016. Ke 37 responden terdiri dari 25 mahasiswi dan 12 mahasiswa. Pengumpulan data pada artikel ini menggunakan pernyataan di kuisioner. Hasil temuan yang diperoleh dari artikel ini adalah mean atau rata-rata responden dalam memahami percakapan berada pada angka 20. Angka tersebut berada di antara angka 19-20 yang menunjuk pada kategori sedang. Kategori ini menggunakan interval standar lima yaitu sangat tinggi, tinggi, sedang, rendah dan sangat rendah. Kesimpulan yang dapat diperoleh adalah kemampuan responden yaitu mahasiswa asing (mahasiswa kelompok propinsi Thailand Selatan) dalam memahami percakapan (baik percakapan teman atau dosen ketika di kelas) menggunakan Bahasa (bahasa Indonesia) berada pada kategori sedang.

Keywords: Bahasa, kemampuan memahami, mahasiswa Thailand Selatan

\section{Pendahuluan}

Universitas Islam Negeri (UIN) Walisongo Semarang adalah salah satu Perguruan Tinggi Keagamaan Islam Negeri (PTKIN) di Indonesia. UIN, seperti perguruan tinggi lain di Indonesia juga melakukan perjanjian kerja sama dalam bidang pendidikan dengan perguruan tinggi lain. Perguruan tinggi tersebut tidak hanya dalam negeri namun juga luar negeri. Salah satu negara yang bekerja sama dengan UIN Walisongo adalah Thailand. Thailand, secara administratif terbagi menjadi 76 propinsi (changwat). Ke 76 propinsi tersebut dikelompokkan ke dalam lima kelompok propinsi yaitu Thailand Utara, Thailand Timur, Thailand Selatan, Thailand Timur Laut dan Thailand Tengah. Nama tiap propinsi berasal dari nama ibu kota propinsinya.

Dari ke lima kelompok propinsi tersebut, UIN Walisongo melakukan kerja sama pendidikan dengan kelompok propinsi Thailand 
Selatan. Kelompok propinsi Thailand Selatan terdiri dari propinsi Chumphon, Krabi, Nakhon Si Thammarat, Narathiwat, Pattani, Phang

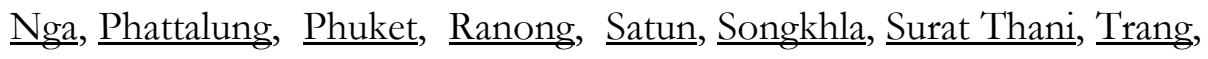
Yala. Dari ke 14 propinsi di Thailand Selatan tersebut, empat diantaranya yaitu Pattani, Yala, Narathiwat dan Satun berpenduduk mayoritas beragama Islam ${ }^{1}$. Jumlah penduduk beragama Islam di Thailand adalah tiga juta jiwa, sebanyak 710.906 jiwa adalah muslim Melayu, selebihnya adalah berasal dari berbagai etnis.

Salah satu dari perjanjian kerja sama pendidikan tersebut adalah pengiriman mahasiswa Thailand Selatan ke UIN Walisongo. Tahun 2013 merupakan tahun awal mula terjadinya pengiriman mahasiswa Thailand Selatan ke UIN Walisongo. Mahasiswa Thailand Selatan tersebut berasal dari propinsi Pattani, Satun, Yala dan Narathiwat yang mayoritas beragama Islam. Pada saat di Thailand Selatan, mahasiswa tersebut sebenarnya sudah atau sedang menempuh pendidikan diploma tiga (D3) di perguruan tinggi asal yang kemudian melanjutkan pendidikan strata satu (S1) di UIN Walisongo dengan bidang pendidikan yang linier. Minat terbesar yang menjadi tujuan melanjutkan pendidikan adalah fakultas Dakwah dan Komunikasi (FDK), fakultas Ilmu Tarbiyah dan Keguruan (FITK), dan fakultas Syariah dan Hukum (FSH). Harapannya ketika kembali ke Thailand Selatan, ilmu linier yang diperoleh di UIN Walisongo

\footnotetext{
${ }^{1}$ Maya Rini Handayani. The Role of Information Technology in Islamic Da'wa Student Development at Pondok Bantan Nakhon Si Thammarat Southern Thailand. (Semarang: Lembaga Penelitian dan Pengabdian kepada Masyarakat IAIN Walisongo Semarang, 2014), 4.
} 
Semarang dapat dipraktikkan dan disebarkan ke sesama rekan-rekan muslim dinegaranya.

Artikel ini membahas mengenai seberapa besar kemampuan memahami arti percakapan yang didengarkan oleh mahasiswa kelompok propinsi Thailand Selatan yang sedang melanjutkan studi di UIN Walisongo. Subjek penelitian sebanyak 37 mahasiswa, semuanya berasal dari kelompok propinsi Thailand Selatan. Thailand Selatan secara geografis lebih dekat dengan Malaysia, sehingga bahasa yang dipergunakan untuk berkomunikasi setiap hari adalah bahasa Melayu. Bahasa Melayu meskipun serumpun dengan bahasa Indonesia (untuk selanjutnya dalam artikel ini disebut Bahasa), tetap memiliki perbedaan yang besar baik dalam bentuk tulisan maupun untuk percakapan. Sulitnya mahasiswa Thailand Selatan dalam memahami Bahasa tidak dapat dipisahkan dengan kemampuan mendengar percakapan yang diucapkan menggunakan Bahasa. Terjadinya salah dalam menanggapi pertanyaan ataupun pernyataan sering terjadi jika berkomuniasi dengan mahasiswa Thailand Selatan. Hal inilah yang menjadi dasar dari penulisan artikel ini. Penulis ingin mengetahui seberapa besar kemampuan mahasiswa Thailand Selatan dalam memahami Bahasa diukur dari kemampuan mendengarkan percakapan.

\section{Metode dan Hasil Penelitian}

Artikel ini merupakan bagian kecil dari sebuah penelitian yang telah dilakukan di tahun 2017. Disebabkan bagian dari sebuah penelitian maka metode penelitian yang digunakan pada artikel ini sama dengan metode pada penelitian terdahulu yaitu kuantitatif deskriptif. Indikator 
yang digunakan adalah kemampuan mendengar percakapan menggunakan Bahasa. Dalam penelitian ini populasinya adalah seluruh mahasiswa kelompok propinsi Thailand Selatan di UIN Walisongo. Populasi merupakan keseluruhan atribut dapat berupa objek atau kejadian yang menjadi fokus penelitian ${ }^{2}$.

Penelitian ini termasuk dalam penelitian populasi. Hal ini didasarkan pada pendapat Arikunto bahwa apabila populasi berjumlah kurang dari 100, maka idealnya seluruh populasi diambil sebagai subjek penelitian, oleh sebab itu penelitian dengan model seperti ini disebut penelitian populasi. Selanjutnya, jika jumlah subjeknya lebih dari 100 dapat diambil sampel antara 10-15\% atau 20-25\% dari jumlah populasi ${ }^{3}$. Metode pengambilan sampel dalam penelitian ini (sampel adalah sebagian atau wakil populasi yang akan diteliti) adalah metode sampling jenuh. Sampling jenuh artinya semua populasi diambil sebagai responden. Hal ini disebabkan jumlah populasi hanya 37 orang yang mana kurang dari 100 orang. Metode sampling jenuh milik Sugiyono sama dengan pendapat Arikunto yang mengatakan jika populasi kurang dari 100 maka lebih baik diambil semua sehingga penelitiannya merupakan penelitian populasi ${ }^{4}$.

Data dikumpulkan menggunakan kuisioner. Proses perhitungan menggunakan SPSS versi 16. Hasil yang diperoleh dari perhitungan

\footnotetext{
${ }^{2}$ Yusuf Muri. Metode Penulisan Kuantitatif, Kualitatif dan Penulisan Gabungan. (Jakarta: Prenada Media Group, 2014), 144

${ }^{3}$ Suharsimi Arikunto. Prosedur Penulisan Suatu Pendekatan Praktek. (Jakarta: PT Renaka Cipta, Jakarta, 2002), 112

${ }^{4}$ Sugiyono. Statistike untuk Penelitian, (Bandung: CV. Alfabeta, 2005)
}

Maya Rini Handayani, Kemampuan Memahami... 
menunjukkan pada angka 20. Angka tersebut berada pada interval 19 hingga 20. Artinya kemampuan mahasiswa Thailand Selatan dalam memahami Bahasa berada pada kategori sedang. Penjelasan lebih rinci disajikan pada bagian pembahasan.

\section{Pembahasan}

\section{Kelompok Propinsi Thailand Selatan}

Sebagaimana penjelasan di atas bahwa Pattani, Yala, Narathiwat dan Satun (termasuk kelompok propinsi di Thailand Selatan) berpenduduk mayoritas beragama Islam. Wilayah Pattani sendiri terbagi menjadi 12 kawasan pentadbiran (amphoe), dibagi lagi menjadi 115 daerah swapraja (tambon) dan 629 buah kampung atau biasa disebut mubaan $^{5}$. Ke 12 wilayah tersebut adalah 1) Mueang Pattani dalam bahasa Thailand มืองปัตตานี dan dalam bahasa Melayu disebut Pattani, 2) Khok Pho dalam bahasa Thailand โคกโพธิ์, 3) Nong Chik dalam bahasa Thailand หนองจิก, 4) Panare dalam bahasa Thailand ปะนาเระ dan bahasa Melayu Panarek, 5) Mayo dalam bahasa Thailand มายอ dan bahasa Melayu Maja, 6) Thung Yang Daeng dalam bahasa Thailand ทุ่งยางแดง, 7) Sai Buri dalam bahasa Thailand สายบุรี dan bahasa Melayu Selindung Bayu, Telube, 8) Mai Kaen dalam bahasa Thailand ไม้แก่น, 9) Yaring dalam bahasa Thailand ยะหริ่ง dan bahasa Melayu Jaring, Jamu, 10) Yarang dalam bahasa Thailand ยะรัง dan

\footnotetext{
${ }^{5}$ Anonim. Wilayah Pattani, https://ms.wikipedia.org/wiki/Wilayah_Pattani. 2017
} 
bahasa Melayu Cegar, 11) Kapho dalam bahasa Thailand กะพ้อ dan terakhir 12) Mae Lan dalam bahasa Thailand แม่ลาน.

\section{Subjek Penelitian}

Subjek penelitian berjumlah 37 mahasiswa (untuk selanjutnya disebut dengan responden). Responden tersebar di 3 fakultas yaitu FDK, FSH, dan FITK. Ke 37 responden merupakan mahasiswa angkatan 2012 hingga 2016. Responden terdiri dari 25 mahasiswi dan 12 mahasiswa. Rentang usia responden berkisar antara 20 hingga 28 tahun $^{6}$. Responden dari FDK berjumlah enam orang, FSH sebanyak empat orang dan FITK berjumlah 27 orang.

Dari ke 12 wilayah propinsi Pattani, responden pada penelitian ini berasal dari daerah Yarang (5 responden), Nong Chik (5 responden), Khok Pho (2 responden), Mueang Pattani (9 responden), Sai Buri (1 responden), Panarek (1 responden), Yaring (1 responden). Sisa responden berasal dari propinsi lain, yaitu Satun (2 responden), Yala (5 responden), Songkhla (2 responden), dan Narathiwat (4 responden). Satun adalah salah satu propinsi yang berdekatan denganTrang, Phattalung dan Songkhla. Sebanyak $67.8 \%$ penduduk Satun adalah Muslim dan 31,9\% adalah Buddha. Mayoritas rakyat Satun adalah orang $\underline{\text { Melayu }}{ }^{7}$.

\footnotetext{
${ }^{6}$ Maya Rini,Handayani. Pengaruh Kemampuan Berbahasa Indonesia terhadap Keberbasilan Studi Mahasiswa Pattani Thailand Selatan di UIN Walisongo Semarang, Semarang: LPPM UIN Walisongo, 2017), 5.

7"Propinsi Satun," diakses 18 Oktober 2017, https://id.wikipedia.org/wiki/Propinsi_Satun.
} 
Yala dalam bahasa Thailand ยะลา adalah propinsi (changwat) Thailand yang terletak di bagian paling selatan. Wilayah-wilayah yang berdekatan dengan Yala adalah Songkhla, Pattani dan Narathiwat. Masyarakat Melayu setempat menyebut wilayah Yala dengan nama Jolor. Penduduk Yala lebih kurang 68.9\% adalah Muslim. Dari 68.9\% tersebut sebanyak $66.1 \%$ nya adalah bangsa $\underline{\text { Melayu }}^{8}$. Bahasa ibu yang digunakan oleh ke empat propinsi tersebut adalah bahasa Melayu Pattani yang berbeda dengan bahasa Melayu apalagi bahasa Indonesia. Perbedaan bahasa kadang kala membuat proses adaptasi seseorang terhadap lingkungan menjadi lebih sulit dan lama. Begitu pula dengan mahasiswa Thailand Selatan yang mengambil pendidikan di UIN Walisongo.

\section{Analisa Deskriptif Kemampuan Mendengar}

Dalam artikel ini, indikator mendengar digunakan sebagai tolok ukur keberhasilan kemampuan berbahasa atau memahami Bahasa. Keberhasilan kemampuan berBahasa dengan indikator mendengar adalah mengukur seberapa jauh kemampuan responden dalam memahami percakapan (baik percakapan teman atau dosen di kelas) menggunakan bahasa Indonesia melalui pendengaran. Pada artikel ini, kemampuan mendengar diukur dengan menggunakan kuisioner yang terdiri dari 7 butir pernyataan. Ke 7 butir tersebut terbagi masingmasing menjadi 4 butir favorable dan 3 butir unfavorable. Butir favorable

\footnotetext{
8“Propinsi Yala," diakses pada 18 Oktober 2018, https://id.wikipedia.org/wiki/Propinsi_Yala.
} 
ditunjukkan pada butir 2, 3, 6, dan 7. Butir unfavorable dinyatakan pada butir 1, 4, dan $5^{9}$.

\section{a. Butir 1 (Unfav)}

Butir 1 merupakan pernyataan negatif yang ditujukan ke responden. Tujuan pernyataan butir 1 untuk mengetahui apakah responden tidak senang dengan mata kuliah bahasa Indonesia. Berikut ini adalah persentase responden terhadap butir 1.

Tabel 2

Persentase Butir 1

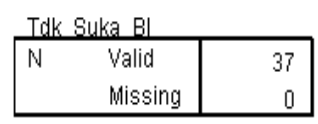

\begin{tabular}{|c|c|c|c|c|c|}
\hline & & Frequency & Percent & Valid Percent & $\begin{array}{l}\text { Cumulative } \\
\text { Percent }\end{array}$ \\
\hline \multirow[t]{4}{*}{ Valid } & Setuju & 9 & 24.3 & 24.3 & 24.3 \\
\hline & Tidak Setuju & 19 & 51.4 & 51.4 & 75.7 \\
\hline & Sangat Tidak Setuju & 9 & 24.3 & 24.3 & 100.0 \\
\hline & Total & 37 & 100.0 & 100.0 & \\
\hline
\end{tabular}

Pada tabel di atas memperlihatkan persentase dari jumlah responden. Sebanyak $24.3 \%$ atau 9 responden memilih jawaban setuju. Lebih dari separuh responden yaitu $51.4 \%$ atau 19 responden memilih jawaban tidak setuju. Jawaban sangat tidak

${ }^{9}$ Maya Rini Handayani. Pengaruh Kemampuan Berbahasa Indonesia terhadap Keberbasilan Studi Mahasiswa Pattani Thailand Selatan (Semarang: LP2M UIN Walisongo Semarang, 2017), 29.

Maya Rini Handayani, Kemampuan Memahami... 
setuju dipilih sebanyak $24.3 \%$ atau 9 responden, sedangkan jawaban sangat setuju tidak ada seorang respondenpun yang memilih. Total dari ketiga jawaban adalah 100\%, artinya semua responden yaitu 37 orang menjawab butir 1 dan valid datanya.

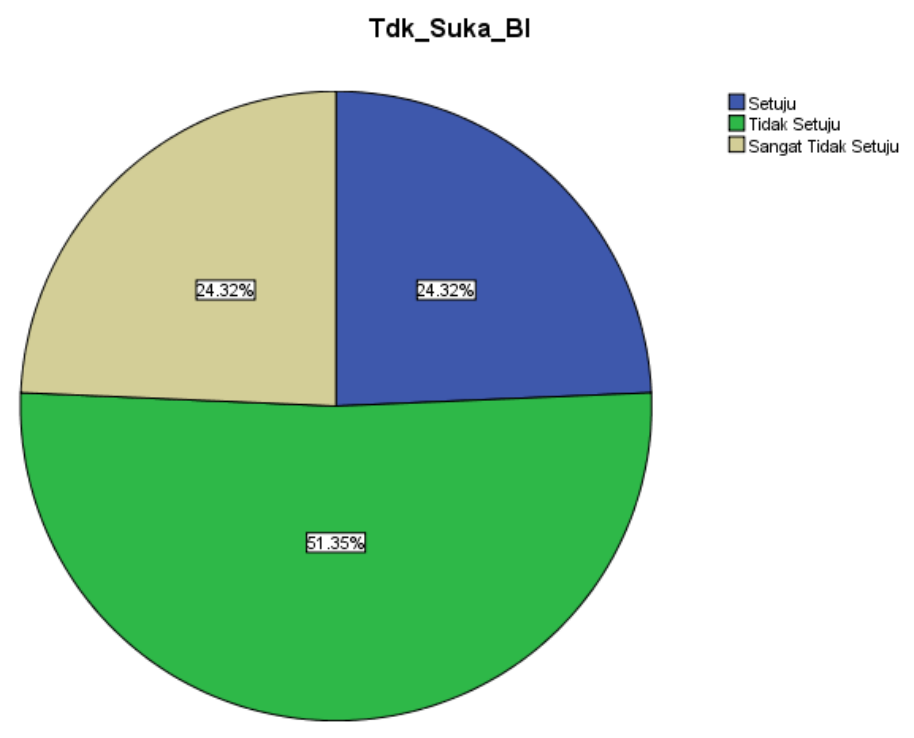

Gambar 1. Diagram Pie Butir 1

Dari diagram di atas terlihat 3 bagian dari diagram Pie. Ketiga bagian tersebut mewakili pernyataan setuju, tidak setuju dan sangat tidak setuju. Dari diagram tersebut dapat diambil kesimpulan bahwa sebanyak $51.35 \%$ (dalam tabel dibulatkan menjadi 51.4\%) atau lebih dari separuh responden tidak setuju dengan pernyataan butir 1 kuisioner. Artinya responden tidak setuju dengan pernyataan butir 1 yang berarti bahwa lebih dari separuh responden mengatakan responden senang dengan mata kuliah Bahasa Indonesia. 


\section{b. Butir 2 (Fav)}

Butir 2 merupakan pernyataan positif yang ditujukan ke responden. Tujuan pernyataan untuk mengetahui apakah responden mendengarkan dengan cermat (memahami) semua kalimat yang diucapkan dosen di kelas. Berikut ini adalah persentase responden terhadap butir 2 .

Tabel 3

Persentase Butir 2

\section{Statistics}

Dar kimt dosen

\begin{tabular}{|rl|r|}
\hline N & Valid & 37 \\
& Missing & 0 \\
\hline
\end{tabular}

\begin{tabular}{|ll|r|r|r|r|}
\hline \multicolumn{1}{|c|}{ Dgr_klmt_dosen } \\
\hline & Frequency & Percent & Valid Percent & $\begin{array}{c}\text { Cumulative } \\
\text { Percent }\end{array}$ \\
\hline Valid & Setuju & 1 & 2.7 & 2.7 & 2.7 \\
& Tidak Setuju & 22 & 59.5 & 59.5 & 62.2 \\
& Sangat Tidak Setuju & 14 & 37.8 & 37.8 & 100.0 \\
& Total & 37 & 100.0 & 100.0 & \\
\hline
\end{tabular}

Pada tabel di atas memperlihatkan persentase dari jumlah responden untuk butir 2. Sebanyak $2.7 \%$ atau 1 responden memilih jawaban setuju. Lebih dari separuh responden yaitu 59.5\% atau 22 responden memilih jawaban tidak setuju. Jawaban sangat tidak setuju dipilih hampir separuh responden yaitu sebanyak $37.8 \%$ atau 14 responden, sedangkan jawaban sangat setuju tidak ada seorang respondenpun yang memilih. Total dari 
ketiga jawaban adalah $100 \%$, artinya semua responden yaitu 37 orang menjawab butir 2 dan valid datanya.

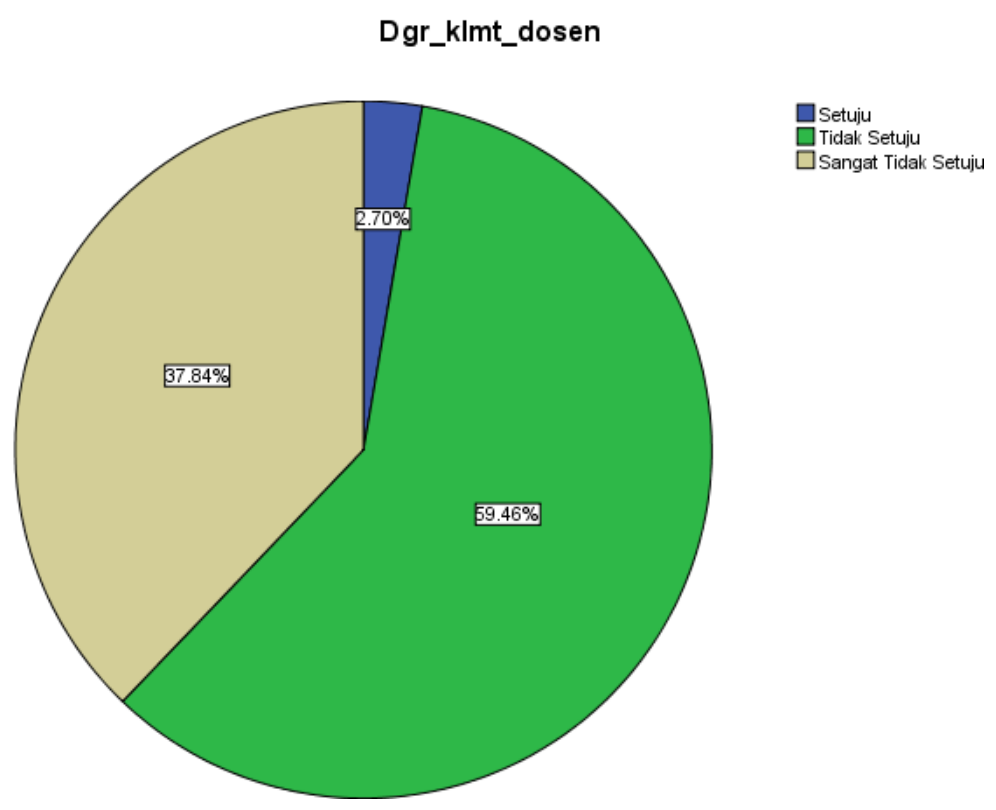

Gambar 2. Diagram Pie Butir 2

Dari diagram di atas terlihat 3 bagian dari diagram Pie untuk butir 2. Ketiga bagian tersebut mewakili pernyataan setuju, tidak setuju dan sangat tidak setuju. Dari diagram tersebut dapat diambil kesimpulan bahwa sebanyak $59.46 \%$ (dalam tabel dibulatkan menjadi 59.5\%) atau lebih dari separuh responden tidak setuju dengan pernyataan butir 2 kuisioner. Artinya responden tidak setuju dengan pernyataan butir 2 yang berarti bahwa lebih dari separuh responden mengatakan responden tidak cermat mendengarkan (memahami) semua kalimat yang diucapkan dosen di kelas. 


\section{c. Butir 3 (Fav)}

Butir 3 merupakan pernyataan positif yang ditujukan ke responden. Tujuan pernyataan untuk mengetahui apakah responden memahami perkataan dosen di kelas, baik secara detail ataupun tidak. Berikut ini adalah persentase responden terhadap butir 3 .

Tabel 4

Persentase Butir 3

\section{Statistics}

Dar kimt dosen
\begin{tabular}{|rr|r|}
\hline N & Valid & 37 \\
& Missing & 0 \\
\hline
\end{tabular}

Dgr_kimt_dosen

\begin{tabular}{|c|c|c|c|c|c|}
\hline & & Frequency & Percent & Valid Percent & $\begin{array}{l}\text { Cumulative } \\
\text { Percent }\end{array}$ \\
\hline \multirow[t]{4}{*}{ Valid } & Setuju & 4 & 10.8 & 10.8 & 10.8 \\
\hline & Tidak Setuju & 27 & 73.0 & 73.0 & 83.8 \\
\hline & Sangat Tidak Setuju & 6 & 16.2 & 16.2 & 100.0 \\
\hline & Total & 37 & 100.0 & 100.0 & \\
\hline
\end{tabular}

Pada tabel di atas memperlihatkan persentase dari jumlah responden untuk butir 3. Sebanyak $10.8 \%$ atau 4 responden memilih jawaban setuju. Hampir tiga perempat responden yaitu 27 orang atau $73 \%$ memilih jawaban tidak setuju. Jawaban sangat tidak setuju dipilih sebanyak $16.2 \%$ atau 6 responden, sedangkan jawaban sangat setuju tidak ada seorang respondenpun yang 
memilih. Total dari ketiga jawaban adalah 100\%, artinya semua responden yaitu 37 orang menjawab butir 3 dan valid datanya.

\section{Dgr_klmt_dosen}

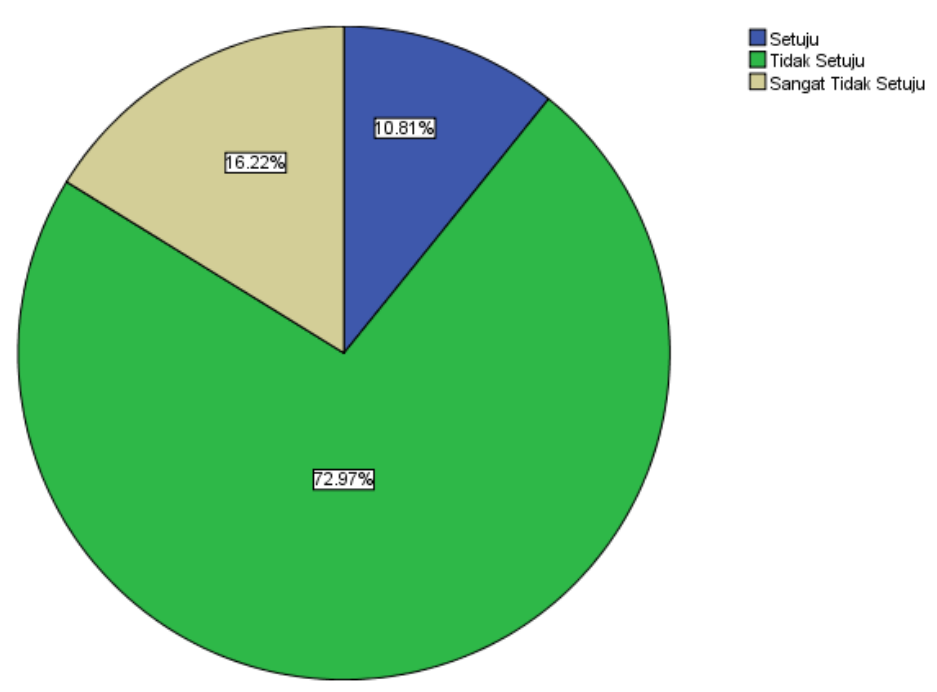

Gambar 3. Diagram Pie Butir 3

Dari diagram di atas terlihat 3 bagian dari diagram Pie untuk butir 3. Ketiga bagian tersebut mewakili pernyataan setuju, tidak setuju dan sangat tidak setuju. Dari diagram tersebut dapat diambil kesimpulan bahwa sebanyak $72.97 \%$ (dalam tabel dibulatkan menjadi $73 \%$ ) atau hampir tiga perempat responden tidak setuju dengan pernyataan butir 3 kuisioner. Artinya responden tidak setuju dengan pernyataan butir 3 yang berarti bahwa hampir tiga perempat responden mengatakan responden tidak memahami perkataan dosen di kelas, baik kata yang diucapkan secara detail ataupun tidak 


\section{d. Butir 4 (Unfav)}

Butir 4 merupakan pernyataan negatif yang ditujukan ke responden. Tujuan pernyataan untuk mengetahui apakah responden kurang memahami pertanyaan dosen di kelas. Berikut ini adalah persentase responden terhadap butir 4 .

Tabel 5

Persentase Butir 4

Statistics

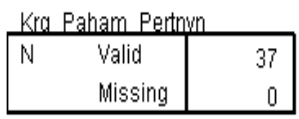

Krg_Paham_Pertmy

\begin{tabular}{|c|c|c|c|c|c|}
\hline & & Frequency & Percent & Valid Percent & $\begin{array}{c}\text { Cumulative } \\
\text { Percent }\end{array}$ \\
\hline \multirow[t]{4}{*}{ Valid } & Sangat Setuju & 8 & 21.6 & 21.6 & 21.6 \\
\hline & Setuju & 14 & 37.8 & 37.8 & 59.5 \\
\hline & Tidak Setuju & 15 & 40.5 & 40.5 & 100.0 \\
\hline & Total & 37 & 100.0 & 100.0 & \\
\hline
\end{tabular}

Pada tabel di atas memperlihatkan persentase dari jumlah responden untuk butir 4 . Sebanyak $21.6 \%$ atau 8 responden memilih jawaban sangat setuju. Jawaban setuju dipilih sebanyak $37.8 \%$ atau 14 responden. Jawaban tidak setuju dipilih sebanyak $40.5 \%$ atau 15 responden, sedangkan jawaban sangat tidak setuju tidak ada seorang respondenpun yang memilih. Total dari ketiga jawaban adalah $100 \%$, artinya semua responden yaitu 37 orang menjawab butir 4 dan valid datanya. 


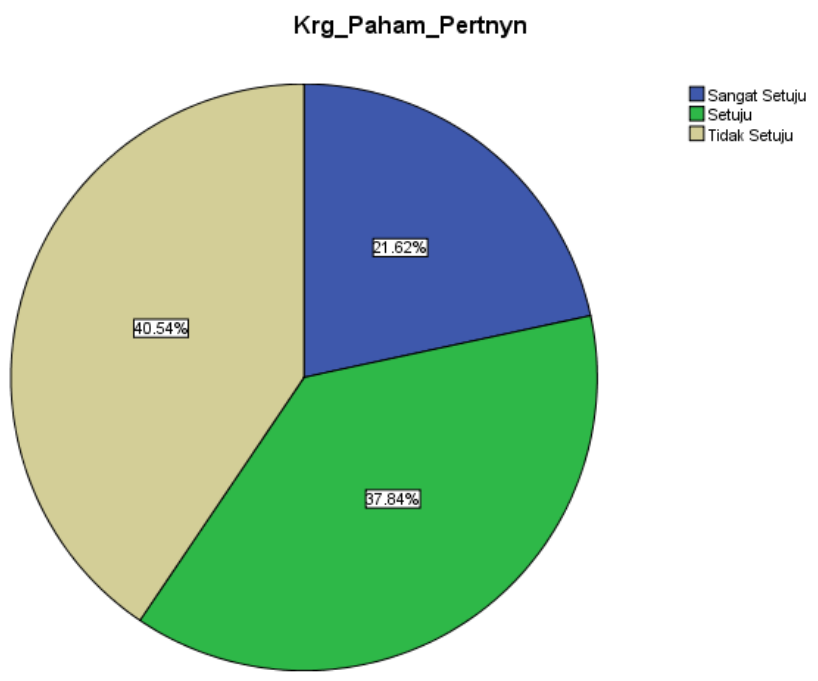

Gambar 4. Diagram Pie Butir 4

Dari diagram di atas terlihat 3 bagian dari diagram Pie untuk butir 4. Ketiga bagian tersebut mewakili pernyataan sangat setuju, setuju dan tidak setuju. Dari diagram tersebut dapat diambil kesimpulan bahwa sebanyak 40.54\% (dalam tabel dibulatkan menjadi 40.5\%) tidak setuju dengan pernyataan butir 4 kuisioner. Artinya responden tidak setuju dengan pernyataan butir 4 yang berarti bahwa responden mengatakan memahami pertanyaan dosen di kelas.

\section{e. Butir 5 (Unfav)}

Butir 5 merupakan pernyataan negatif yang ditujukan ke responden. Tujuan pernyataan untuk mengetahui apakah responden hanya paham satu atau dua kata dalam percakapan. Berikut ini adalah persentase responden terhadap butir 5 . 
Tabel 6

Persentase Butir 5

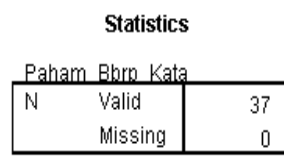

\begin{tabular}{|c|c|c|c|c|c|}
\hline \multicolumn{6}{|c|}{ Paham_Bbrp_Kata } \\
\hline & & Frequency & Percent & Valid Percent & $\begin{array}{l}\text { Cumulative } \\
\text { Percent }\end{array}$ \\
\hline \multirow[t]{5}{*}{ Valid } & Sangat Setuju & 5 & 13.5 & 13.5 & 13.5 \\
\hline & Setuju & 11 & 29.7 & 29.7 & 43.2 \\
\hline & Tidak Setuju & 19 & 51.4 & 51.4 & 94.6 \\
\hline & Sangat Tidak Setuju & 2 & 5.4 & 5.4 & 100.0 \\
\hline & Total & 37 & 100.0 & 100.0 & \\
\hline
\end{tabular}

Pada tabel di atas memperlihatkan persentase dari jumlah responden untuk butir 5. Sebanyak $13.5 \%$ atau 5 responden memilih jawaban sangat setuju. Jawaban setuju dipilih sebanyak 29.7\% atau 11 responden. Jawaban tidak setuju dipilih lebih dari separuh responden sebanyak $51.4 \%$ atau 19 responden, sedangkan jawaban sangat tidak setuju dipilih oleh 2 responden atau 5.4\%. Total dari keempat jawaban adalah 100\%, artinya semua responden yaitu 37 orang menjawab butir 5 dan valid datanya. 


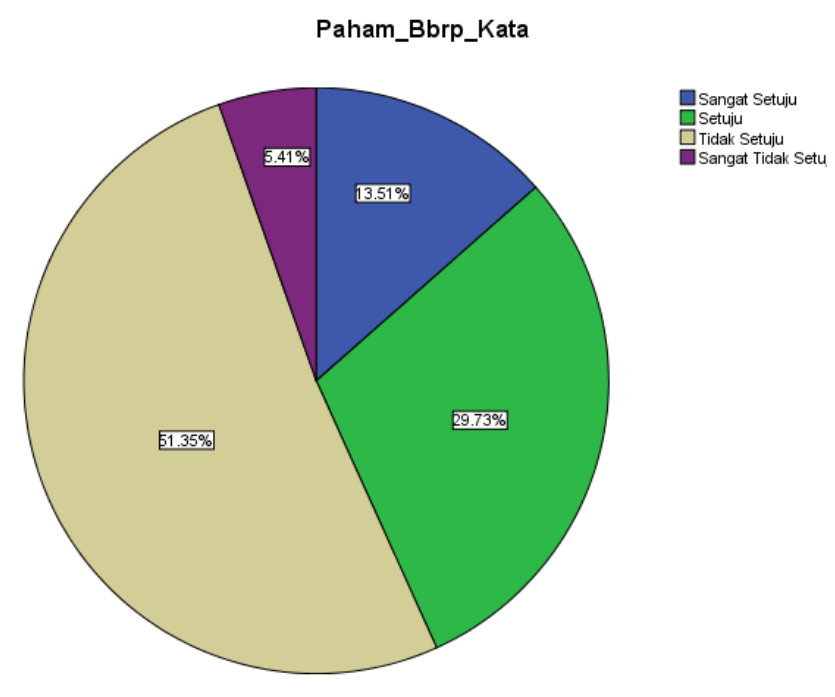

Gambar 5. Diagram Pie Butir 5

Dari diagram di atas terlihat 4 bagian dari diagram Pie untuk butir 5. Dari diagram tersebut dapat diambil kesimpulan bahwa sebanyak 51.35\% (dalam tabel dibulatkan menjadi 51.4\%) tidak setuju dengan pernyataan butir 5 kuisioner. Artinya responden tidak setuju dengan pernyataan butir 5 yang berarti bahwa responden paham banyak kata yang diucapkan selama percakapan berlangsung.

\section{f. Butir 6 (Fav)}

Butir 6 merupakan pernyataan positif yang ditujukan kepada responden. Tujuan pernyataan untuk mengetahui apakah responden senang mendengarkan percakapan teman Indonesia di kelas. Berikut ini adalah persentase responden terhadap butir 6 . 
Tabel 7

Persentase Butir 6

Senang Dar
\begin{tabular}{|ll|r|}
\hline N & Valid & 37 \\
& Missing & 0 \\
\hline
\end{tabular}

\begin{tabular}{|c|c|c|c|c|c|}
\hline \multicolumn{6}{|c|}{ Senang_Dgr } \\
\hline & & Frequency & Percent & Valid Percent & $\begin{array}{l}\text { Cumulative } \\
\text { Percent }\end{array}$ \\
\hline \multirow[t]{4}{*}{ Valid } & Setuju & 9 & 24.3 & 24.3 & 24.3 \\
\hline & Tidak Setuju & 17 & 45.9 & 45.9 & 70.3 \\
\hline & Sangat Tidak Setuju & 11 & 29.7 & 29.7 & 100.0 \\
\hline & Total & 37 & 100.0 & 100.0 & \\
\hline
\end{tabular}

Pada tabel di atas memperlihatkan persentase dari jumlah responden untuk butir 6. Sebanyak $24.3 \%$ atau 9 responden memilih jawaban setuju. Jawaban tidak setuju dipilih hampir separuh responden yaitu sebanyak 45.9\% atau 17 responden. Jawaban sangat tidak setuju dipilih sebanyak 29.7\% atau 11 responden, sedangkan jawaban sangat setuju tidak ada seorang respondenpun yang memilih. Total dari ketiga jawaban adalah 100\%, artinya semua responden yaitu 37 orang menjawab butir 6 dan valid datanya. 


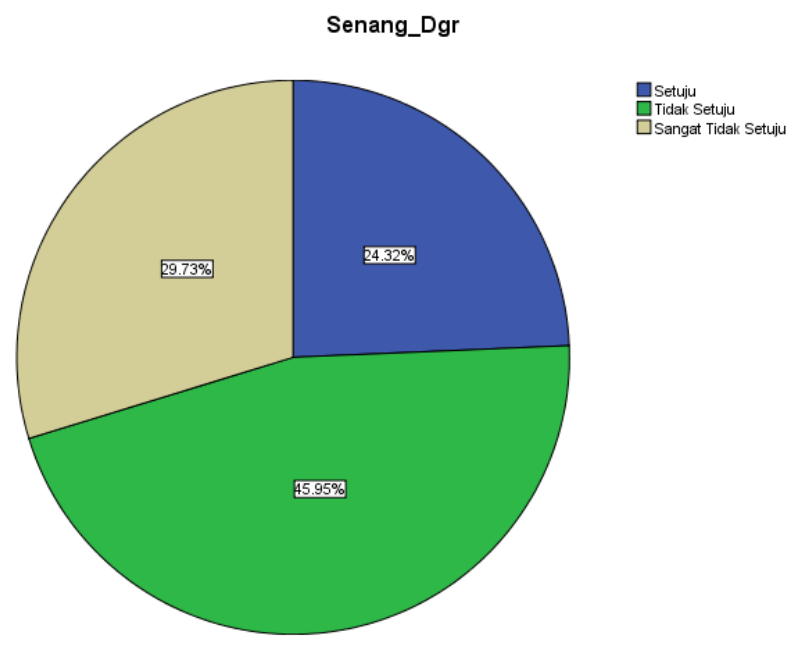

Gambar 6. Diagram Pie Butir 6

Dari diagram di atas terlihat 3 bagian dari diagram Pie untuk butir 6. Ketiga bagian tersebut mewakili pernyataan setuju, tidak setuju dan sangat tidak setuju. Dari diagram tersebut dapat diambil kesimpulan bahwa sebanyak 45.95\% (dalam tabel dibulatkan menjadi 45.9\%) tidak setuju dengan pernyataan butir 6 kuisioner. Artinya responden tidak setuju dengan pernyataan butir 6 yang berarti bahwa responden tidak senang mendengarkan percakapan teman Indonesia di kelas.

\section{g. Butir 7 (Fav)}

Butir 7 merupakan pernyataan positif yang ditujukan ke responden. Tujuan pernyataan butir 7 untuk mengetahui apakah responden paham inti atau garis besar percakapan teman di kelas atau orang lain. Berikut ini adalah persentase responden terhadap butir 7 . 
Tabel 8

Persentase Butir 7

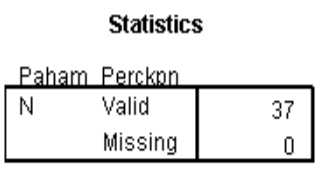

Paham_Perckpn

\begin{tabular}{|c|c|c|c|c|c|}
\hline & & Frequency & Percent & Valid Percent & $\begin{array}{l}\text { Cumulative } \\
\text { Percent }\end{array}$ \\
\hline \multirow[t]{4}{*}{ Valid } & Setuju & 11 & 29.7 & 29.7 & 29.7 \\
\hline & Tidak Setuju & 23 & 62.2 & 62.2 & 91.9 \\
\hline & Sangat Tidak Setuju & 3 & 8.1 & 8.1 & 100.0 \\
\hline & Total & 37 & 100.0 & 100.0 & \\
\hline
\end{tabular}

Pada tabel di atas memperlihatkan persentase dari jumlah responden untuk butir 7. Sebanyak 29.7\% atau 11 responden memilih jawaban setuju. Jawaban tidak setuju dipilih lebih dari separuh responden yaitu sebanyak $62.2 \%$ atau 23 responden. Jawaban sangat tidak setuju dipilih sebanyak $8.1 \%$ atau 3 responden, sedangkan jawaban sangat setuju tidak ada seorang respondenpun yang memilih. Total dari ketiga jawaban adalah 100\%, artinya semua responden yaitu 37 orang menjawab butir 7 dan valid datanya. 


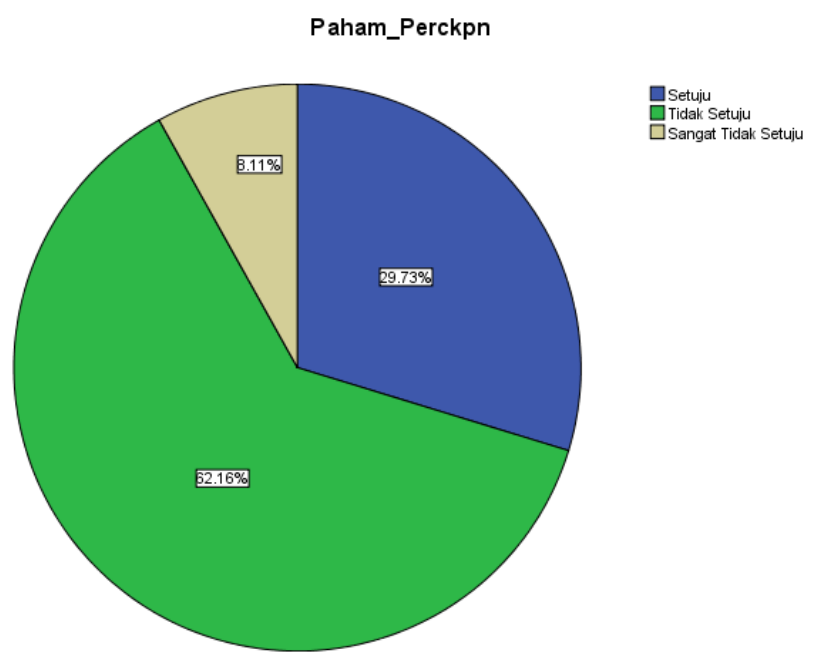

Gambar 7. Diagram Pie Butir 7

Dari diagram di atas terlihat 3 bagian dari diagram Pie untuk butir 7. Ketiga bagian tersebut mewakili pernyataan setuju, tidak setuju dan sangat tidak setuju. Dari diagram tersebut dapat diambil kesimpulan bahwa sebanyak $62.16 \%$ (dalam tabel dibulatkan menjadi 62.2\%) tidak setuju dengan pernyataan butir 7 kuisioner. Artinya responden tidak setuju dengan pernyataan butir 7 yang berarti bahwa responden tidak paham inti atau garis besar percakapan teman di kelas atau orang lain.

Analisa deskriptif digunakan untuk mengetahui persentase setiap butir pernyataan sesuai dengan indikator yang digunakan. Meskipun demikian, analisa tersebut belumlah bisa digunakan untuk menarik sebuah kesimpulan dari penelitian ini. Penelitian ini bertujuan mencari seberapa baikkah kemampuan responden memahami percakapan teman atau dosen menggunakan Bahasa 
baik di kelas maupun di luar kelas. Untuk menjawab pertanyaan tersebut maka dicarilah mean (rata-rata) dan standar deviasi untuk nilai total 7 butir pernyataan sesuai dengan indikator yang digunakan. Pencarian penghitungan mean dan standar deviasi menggunakan bantuan SPSS ver. 16, hasilnya seperti pada tabel di bawah ini :

Tabel 9

Mean dan Standar Deviasi

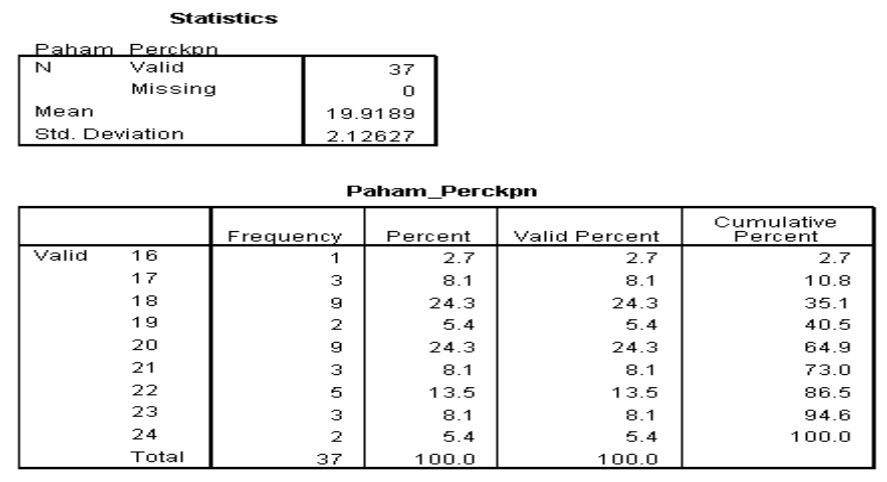

Dari tabel di atas terlihat $\mathrm{N}$ sebanyak 37 responden, mean sebesar 19.9189 yang kemudian dibulatkan menjadi 20. Standar deviasi yang ditemukan adalah sebesar 2.12627 yang dibulatkan menjadi 2. Hasil mean dan standar deviasi digunakan sebagai acuan untuk membuat interval standar lima ${ }^{10}$. Interval diukur dengan menggunakan rumus seperti yang terlihat pada tabel di bawah ini

\footnotetext{
${ }^{10}$ Anas Sudijono. Pengantar Evaluasi Pendidikan, (Jakarta: Rajawali Press, 2009), 452-453.
} 
Tabel 10

Perhitungan Interval Kemampuan Mendengar

\begin{tabular}{ll}
\hline \multicolumn{1}{c}{ Rumus } & \multicolumn{1}{c}{ Perhitungan } \\
\hline Mean $+1,5$ (Standar Deviasi) & $20+1,5(2)=23$ \\
Mean $+0,5$ (Standar Deviasi) & $20+0,5(2)=21$ \\
Mean - 0,5 (Standar Deviasi) & $20-0,5(2)=19$ \\
Mean - 1,5 (Standar Deviasi) & $20-1,5(2)=17$ \\
\hline
\end{tabular}

Tabel di atas memperlihatkan interval mean (rata-rata) kemampuan mendengar percakapan Bahasa dari ke 37 responden. Perhitungan menggunakan mean $+1,5$ (Standar Deviasi) diperoleh angka 23. Perhitungan ke 2 yaitu mean $+0,5$ (Standar Deviasi) diperoleh 21. Perhitungan ke 3, mean - 0,5 (Standar Deviasi) diperoleh 19, dan yang terakhir mean - 1,5 (Standar Deviasi) diperoleh 17. Dari perhitungan tersebut terlihat bahwa batas angka tertinggi adalah 23 dan batas angka terendah adalah 17 untuk kategorisasi standar lima. Artinya dari angka 17 hingga 23 adalah rentang atau interval yang akan digunakan untuk mengukur dan mengambil kesimpulan kemampuan mendengar responden. Hal itu dikuatkan dengan perhitungan mean yang berada di antara angka tersebut. Tabel berikut ini akan memperjelas interval kemampuan mendengar percakapan berBahasa responden yang telah diukur. 
Tabel 11

Interval Kemampuan Mendengar

\begin{tabular}{lll}
\hline No & Interval & Kategori \\
\hline 1. & 23 ke atas & Sangat Tinggi \\
2. & $21-22$ & Tinggi \\
3. & $19-20$ & Sedang \\
4. & $17-18$ & Rendah \\
5. & 16 ke bawah & Sangat Rendah \\
\hline
\end{tabular}

Pada tabel di atas, interval diperoleh dari perhitungan tabel 11 dengan kategori sebanyak 5 standar. Mean dari indikator mendengar pada penelitian ini sebesar 20 (perhatikan tabel 9). Apabila dibandingkan dengan interval pada tabel 11 maka akan terlihat bahwa angka 20 berada di antara angka 19 - 20 (baris ke 3). Rentang 19 - 20 menunjuk pada kategori sedang. Kesimpulan yang dapat diambil dari temuan hasil pada penelitian ini adalah kemampuan memahami percakapan responden menggunakan bahasa Indonesia (Bahasa) di UIN Walisongo Semarang berada pada kategori sedang.

\section{Kesimpulan}

Berdasarkan temuan hasil pada artikel ini dapat disimpulkan bahwa kemampuan memahami percakapan mahasiswa kelompok propinsi Thailand Selatan menggunakan Bahasa berada pada kategori sedang. Artinya rata-rata mahasiswa Thailand yang kuliah di UIN Walisongo cukup mampu untuk memahami percakapan dengan menggunakan Bahasa sehingga mempermudah dalam mengerti dan menjawab pertanyaan atau percakapan. Mahasiswa kelompok propinsi Thailand Selatan hendaknya sering berlatih mendengarkan percakapan menggunakan Bahasa. Meningkatnya frekuensi mendengarkan percakapan sehari-hari yang dilakukan dengan teman Indonesia ataupun 
sesama teman Thailand menyebabkan meningkat pula kemampuan dalam memahami percakapan dengan menggunakan Bahasa.

\section{Referensi}

Arikunto, Suharsimi. 2002. Prosedur Penulisan Suatu Pendekatan Praktek. Hal. 112. PT Renaka Cipta. Jakarta.

Handayani, Maya Rini. The Role of Information Technology in Islamic Da'wa Student Development at Pondok. Bantan Nakhon Si Thammarat Southern Thailand. Lembaga Penelitian dan Pengabdian kepada Masyarakat IAIN Walisongo Semarang. 2014

Handayani, Maya Rini. Pengarub Kemampuan Berbahasa Indonesia terhadap Keberhasilan Studi Mahasiswa Pattani Thailand Selatan di UIN Walisongo Semarang. Penelitian dibiayai oleh LPPM UIN Walisongo tahun anggaran 2017. 2017

Yusuf, Muri. Metode Penulisan Kuantitatif, Kualitatif dan Penulisan Gabungan. Jakarta. Prenada Media Group. 2014

Sugiyono. Statistika untuk Penelitian. Bandung: CV. Alfabeta. 2005

Sudijono, Anas. Pengantar Evaluasi Pendidikan. Jakarta: Rajawali Pres. 2009

Wikipedia. "Pattani Thailand." Diakses pada tanggal 24 Februari 2017. https://en.wikipedia.org/wiki/Pattani,_Thailand.

Wikipedia. “Thailand”. Diakses pada tanggal 18 Oktober 2017. http://id.wikipedia.org/wiki/Thailand.

Wikipedia. "Propinsi Yala". Diakses pada tanggal 18 Oktober 2017. https://id.wikipedia.org/wiki/ Propinsi_Yala.

Wikipedia. “Propinsi Pattani”. Diakses pada tanggal 18 Oktober 2017. https://id.wikipedia.org/wiki/Propinsi_Pattani.

Wikipedia. “Wilayah Pattani”. Diakses pada tanggal 18 Oktober 2017. https://ms.wikipedia.org/wiki/Wilayah_Pattani.

Wikipedia. "Propinsi Satun". Diakses pada tanggal 18 Oktober 2017. https://id.wikipedia.org/wiki/Propinsi_Satun. 